January 2003 • NREL/CP-550-33208

\title{
Reducing the Cost of Energy from Parabolic Trough Solar Power Plants
}

\section{Preprint}

\author{
H. Price
}

National Renewable Energy Laboratory

D. Kearney

Kearney \& Associates

To be presented at the ISES 2003:

International Solar Energy Conference

Hawaii Island, Hawaii

March 16-18, 2003

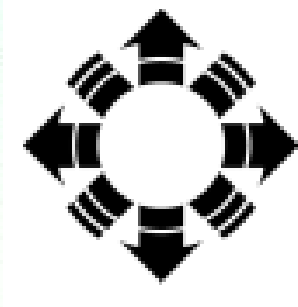

\section{NPEI}

National Renewable Energy Laboratory

1617 Cole Boulevard

Golden, Colorado 80401-3393

NREL is a U.S. Department of Energy Laboratory

Operated by Midwest Research Institute $\bullet$ Battelle $\bullet$ Bechtel

Contract No. DE-AC36-99-G010337 


\section{NOTICE}

The submitted manuscript has been offered by an employee of the Midwest Research Institute (MRI), a contractor of the US Government under Contract No. DE-AC36-99G010337. Accordingly, the US Government and MRI retain a nonexclusive royalty-free license to publish or reproduce the published form of this contribution, or allow others to do so, for US Government purposes.

This report was prepared as an account of work sponsored by an agency of the United States government. Neither the United States government nor any agency thereof, nor any of their employees, makes any warranty, express or implied, or assumes any legal liability or responsibility for the accuracy, completeness, or usefulness of any information, apparatus, product, or process disclosed, or represents that its use would not infringe privately owned rights. Reference herein to any specific commercial product, process, or service by trade name, trademark, manufacturer, or otherwise does not necessarily constitute or imply its endorsement, recommendation, or favoring by the United States government or any agency thereof. The views and opinions of authors expressed herein do not necessarily state or reflect those of the United States government or any agency thereof.

Available electronically at http://www.osti.gov/bridge

Available for a processing fee to U.S. Department of Energy and its contractors, in paper, from:

U.S. Department of Energy

Office of Scientific and Technical Information

P.O. Box 62

Oak Ridge, TN 37831-0062

phone: 865.576.8401

fax: 865.576.5728

email: reports@adonis.osti.gov

Available for sale to the public, in paper, from:

U.S. Department of Commerce

National Technical Information Service

5285 Port Royal Road

Springfield, VA 22161

phone: 800.553 .6847

fax: 703.605.6900

email: orders@ntis.fedworld.gov

online ordering: http://www.ntis.gov/ordering.htm

Printed on paper containing at least $50 \%$ wastepaper, including $20 \%$ postconsumer waste 


\section{REDUCING THE COST OF ENERGY FROM PARABOLIC TROUGH SOLAR POWER PLANTS}

\author{
Henry Price \\ National Renewable Energy Laboratory \\ 1617 Cole Blvd., Golden, CO, 80401 \\ henry_price@nrel.gov
}

\author{
David Kearney \\ Kearney \& Associates \\ P.O. Box 2568, Vashon, WA, 98070 \\ dkearney@attglobal.net
}

\begin{abstract}
Parabolic trough solar technology is the most proven and lowest cost large-scale solar power technology available today, primarily because of the nine large commercial-scale solar power plants that are operating in the California Mojave Desert. However, no new plants have been built during the past ten years because the cost of power from these plants is more expensive than power from conventional fossil fuel power plants. This paper reviews the current cost of energy and the potential for reducing the cost of energy from parabolic trough solar power plant technology based on the latest technological advancements and projected improvements from industry and sponsored R\&D. The paper also looks at the impact of project financing and incentives on the cost of energy.
\end{abstract}

\section{INTRODUCTION}

This paper provides an assessment of the cost of power for parabolic trough solar power technology for large-scale gridconnected power applications, for both near-term and future parabolic trough solar power plants.

The development and operation of the SEGS plants by Luz International Ltd. - totaling 354 MWe net installed capacity provide a firm initial basis for future performance and cost projections. All are still in operation, best represented by the five 30-MWe plants operated by KJC Operating Co. at Kramer Junction, California. The Luz group failed in 1991, but technology development in the United States continued in the 1990s [1,2].

The cost of energy can be reduced through technology improvements, scale-up in individual plant MW capacity, increased deployment rates, competitive pressures, use of thermal storage, and advancements in O\&M methods. The cost of energy can also be reduced through lower cost financing and through taxation or investment incentives. The United States and European parabolic trough industries have developed proprietary plans for lowering costs in future trough power plants. The evaluation given here provides a cost estimate that generally agrees with industry expectations for R\&D advances in component and subsystem improvements.

\section{METHODOLOGY}

This paper draws upon known data from technology improvements, R\&D plans, and expected gains to project both reductions in investment costs and increases in performance. These data have been utilized in an NREL-developed model for evaluating the performance and economics of parabolic trough power plants, the primary metric being the levelized cost of electricity [3]. The model includes an hourly performance simulation module, a capital cost module, an O\&M cost module, and a project-financing module. The performance module has been validated against the actual performance at the SEGS plants. For this study, the model predicted the annual gross solar-to-electric performance of SEGS VI during 1999 within $1 \%$ when using actual solar field availabilities, collector receiver conditions, mirror reflectivity and site solar radiation data. The capital cost module is in part based on detailed cost data from Flabeg Solar International [4]. The O\&M cost module is based in part on data from KJC Operating Company. The project finance module is a 30 -year cash flow model for evaluating independent power producer (IPP) power plant projects.

The evaluation reported here also draws from a recent study [5] that examines the cost expectations for near-term, mid-term, and long-term trough power plants, generally covering the time frames of 2004, 2010, and 2020. 


\section{Reference Plant}

Potential parabolic trough plant cost reductions are discussed from a reference point of the operating SEGS plants in the California Mojave Desert. The efficiency of existing parabolic trough plants has been well characterized and provides a good basis for evaluating the potential performance improvements of future parabolic trough plants. We have used the 30-MWe SEGS VI plant as our reference plant for evaluating future cost and performance of trough plants. We selected SEGS VI as a reference because:

- it is the last of the SEGS plants that uses the LS-2 collector for the full solar field. The LS-2 collector has demonstrated the best overall O\&M characteristics of the three collector designs used at the SEGS plants.

- it operates at the higher temperature also used at the later 80 -MWe plants, with steam conditions of 100 bar and $371^{\circ} \mathrm{C}$.

- the operator (KJC Operating Company) has provided detailed operation and maintenance data on the plant.

The NREL model has been used to model the cost and performance of the 30-MWe SEGS VI plant. The SEGS VI plant is a hybrid plant and can produce electricity from both solar energy and natural gas. Federal law allows the SEGS plants to use $25 \%$ fossil fuel heat input into the steam on an annual basis. Table 1 shows the general design, cost, and performance characteristics of the $30-\mathrm{MWe}$ trough plant. The solar field constitutes approximately $60 \%$ of the direct costs. While the technology is assumed to be the same as used in SEGS VI, the capital costs are based on current cost projections [4]. The calculated levelized cost of energy or LCOE [6] is based on current financial assumptions assumed to be available to a large-scale trough plant built in the United States ${ }^{1}$ and is stated in constant or real 2002 U.S. dollars. Unless otherwise noted, the analysis uses the 1999 insolation data from Kramer Junction, California (2,940 kWh/m2-yr).

The resulting cost of power for the 30-MWe SEGS VI trough plant, if built today, is $17.0 \notin / \mathrm{kWh}$ for a solar-only plant and $14.1 \mathrm{c} / \mathrm{kWh}$ for the hybrid plant.

\section{Near-Term Trough Plants}

A number of new parabolic trough power plant projects are currently under consideration around the world. The technology used in these projects will build on the equipment and experience from the SEGS plants. In addition, important advances have occurred since the last parabolic trough plant was built that will have an impact on the efficiency and cost of the next plants built.

\footnotetext{
${ }^{1}$ Financing Assumptions: $8.5 \%$ debt interest rate, 20-year debt term, 1.35 debt service coverage ratio, $14 \%$ equity internal rate of return, 30 -year project life, annual insurance cost $0.5 \%$ of capital cost, annual property tax $0.5 \%$ of capital cost, $10 \%$ Investment Tax Credit (ITC), 5-year MACRS, $2.5 \%$ inflation.
}

Table 1 Reference 30 MWe SEGS Plant

\begin{tabular}{lcc}
\hline Site: Kramer Junction & $\begin{array}{c}\text { Solar } \\
\text { Only }\end{array}$ & $\begin{array}{c}\text { Hybrid } \\
(\mathbf{2 5 \%})\end{array}$ \\
\hline Plant size, net electric $(\mathrm{Mwe})$ & 30 & 30 \\
Collector aperture Area $\left(\mathrm{km}^{2}\right)$ & 0.188 & 0.188 \\
Thermal storage (hours) & 0 & 0 \\
Solar-to-electric efficiency $(\%)$ & $10.6 \%$ & $10.7 \%$ \\
Plant Capacity factor $(\%)$ & $22.2 \%$ & $30.4 \%$ \\
Capital cost $(\$ / \mathrm{kWe})$ & 3,008 & 3,204 \\
O\&M cost $(\$ / \mathrm{kWh})$ & 0.046 & 0.034 \\
Fuel cost $(\$ / \mathrm{kWh})$ & 0.000 & 0.013 \\
LCOE $[2002 \$ / \mathrm{kWh}]$ & 0.170 & 0.141 \\
\hline
\end{tabular}

The KJC Operating Company (KJCOC) operation and maintenance $(\mathrm{O} \& \mathrm{M})$ cost reduction program [1] resulted in a number of key advances that have significantly reduced O\&M costs. Key among these are improvements in mirror washingtechniques, improved heat-transfer fluid pump seal O\&M practices, improved O\&M practices for reducing receiver tube failures, and improved control and information systems.

Solel Solar Systems has recently developed a new parabolic trough receiver referred to as the universal vacuum (UVAC) receiver. The UVAC has improved thermal and optic properties. Field tests of the new receiver at SEGS VI shows a $20 \%$ increase in thermal performance compared to original receiver tubes.

KJCOC has also implemented a new piping interconnection for the piping interface between collectors, referred to as balljoint assemblies, for replacement of the original flexible hoses. A demonstration test of new ball-joint assemblies has been shown to reduce the hydraulic pressure drop in the solar field by approximately $50 \%$. This results in significantly lower solar field heat transfer fluid pumping electric parasitics.

Based on the advances in parabolic trough technology mentioned above, our baseline reference near-term plant will have the following characteristics:

- $50 \mathrm{MWe}$ net electric output. This size is currently being planned for several new trough plants

- LS-2 parabolic trough collectors. The LS-2 is one of several collector configurations being considered in near-term projects. The LS-2 represents the lowest risk and most conservative technology assumption

- UVAC receiver. The new Solel receiver has been demonstrated at the SEGS plants and will be the receiver of choice for new projects

- Ball-joint assemblies in place of flex hoses. These have been extensively demonstrated at the SEGS plants

- O\&M improvements to reduce receiver failures and improve mirror reflectivity. 
Table 2 shows the characteristics of the near-term baseline trough configuration. Solar-to-electric efficiency is expected to improve by approximately one-third in near-term plants over the original SEGS plants, in large part due to the new Solel receiver and the use of ball-joint assemblies. Unit capital costs are lower because of the larger plant capacity and the more efficient solar field, which helps reduce the size of solar field required. The levelized cost of energy is reduced by about $30-35 \%$ from the original SEGS plants.

Table 2 Baseline Near-Term Trough Plant

\begin{tabular}{lcc}
\hline Site: Kramer Junction & $\begin{array}{c}\text { Solar } \\
\text { Only }\end{array}$ & $\begin{array}{c}\text { Hybrid } \\
(\mathbf{2 5 \% )}\end{array}$ \\
\hline Plant size, net electric $(\mathrm{MWe})$ & 50 & 50 \\
Collector aperture area $\left(\mathrm{km}^{2}\right)$ & 0.312 & 0.312 \\
Thermal storage (hours) & 0 & 0 \\
Solar-to-electric efficiency $(\%)$ & $13.9 \%$ & $14.1 \%$ \\
Plant capacity factor $(\%)$ & $29.2 \%$ & $39.6 \%$ \\
Capital cost $(\$ / \mathrm{kWe})$ & 2,745 & 2,939 \\
O\&M cost $(\$ / \mathrm{kWh})$ & 0.024 & 0.018 \\
Fuel cost $(\$ / \mathrm{kWh})$ & 0.000 & 0.010 \\
LCOE $(2002 \$ / \mathrm{kWh})$ & 0.110 & 0.096 \\
\hline
\end{tabular}

\section{COST REDUCTION OPPORTUNITIES}

Although significant cost reductions have occurred since the SEGS plants, these prices are not attractive in the current competitive power market. Studies have shown [7] that the cost of power from a trough plant would need to be on the order of $5 \notin / \mathrm{kWh}$ to be directly competitive with fossil fuel alternatives at current 2002 fossil prices. A recent assessment has just been completed for the U.S. Department of Energy (DOE) to evaluate the long-term cost reduction potential of parabolic trough technology [5]. A basic conclusion of that study was that the cost of power from parabolic trough technology could be markedly reduced through scale-up of the plant, technology advances, commercial deployment, and financial incentives.

In this section we quantify, using the NREL model, the cost reduction potential of the following specific opportunities: plant scale-up, integration with combined cycle plants, improved receiver technology, advanced concentrator designs, the addition of thermal energy storage, and financial incentives.

\section{Plant Scale-up}

One of the primary opportunities for reducing cost is to increase the size of the power plant. In general, power plant equipment costs $(\$ / \mathrm{kWe})$ decrease with the size of the plant [5]. O\&M costs also reduce with plant capacity because it typically takes a power plant O\&M crew of about the same size to run a 30-MWe steam plant as it would to run a 200-MWe steam plant. The largest plant built by Luz was limited to 80 MWe by thencurrent FERC rules for plants to qualify as renewal energy plants under applicable laws. Luz planning also included consideration of larger plant sizes in the 150 to 200 MWe range [8]. The upper limit is defined by a tradeoff between economies of scale and the parasitics involved with the pumping of heattransfer fluid through the solar field. By replacing flexible hoses with ball-joint assemblies, sizes of $400 \mathrm{MWe}$ or more are feasible because of the much lower pumping parasitics since the major solar system pressure losses are found in the solar collector loops, not in the main headers.

Figure 1 shows the impact on the cost of energy for different size power plants. A 400-MW solar-only trough plant has the potential to produce power for less than $8 \notin / \mathrm{kWh}$, whereas the cost of power from the baseline 50-MW plant is $11 \notin / \mathrm{kWh}$, independent of other factors such as technical improvements. This is obviously a very important parameter. It should also be noted that many of the advantages achieved in scaling up a plant can also be achieved by siting multiple plants together in a power park.

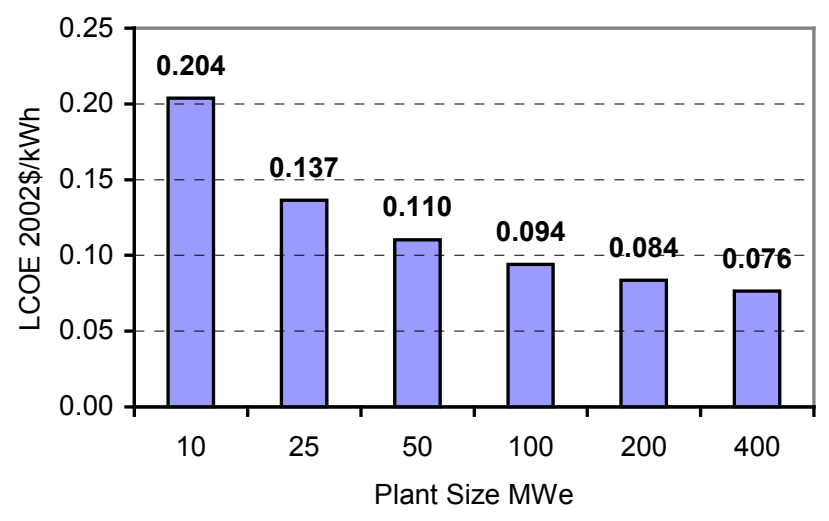

Figure 1 Impact of Plant Size on Cost of Energy

\section{Integrated Solar Combined-Cycle System (ISCCS)}

The ISCCS configuration is currently being considered for a number of the Global Environment Facility (GEF) trough projects [5]. The ISCCS integrates solar steam into the Rankine steam bottoming cycle of a combined-cycle power plant. The general concept is to oversize the steam turbine to handle the increased steam capacity. At the high end, steam turbine capacity can be approximately doubled, with solar heat being used for steam generation and gas turbine waste heat being used for preheating and superheating steam. However, when solar energy is not available the steam turbine must run at part load and thus at reduced efficiency. Doubling the steam turbine capacity would result in approximately a $25 \%$ design point solar contribution. Because solar energy is only available about $25 \%$ of the time, the annual solar contribution for trough plant without thermal storage would only be about $10 \%$ for a baseload combined-cycle plant. Studies show that the optimum solar contribution is typically less than the maximum. This is because the more the steam turbine is oversized, the greater the off-design impact on the fossil plant when solar is not available. 
These issues are discussed in detail in a recent paper by Dersch [9]. Table 3 shows the cost and performance of the 40-MW solar increment of an ISCCS plant ${ }^{2}$ compared to the baseline 50-MWe Rankine cycle plant. The fuel cost is the result of the steam turbine heat rate performance penalty when solar is not available compared to the reference combined cycle plant. The ISCCS configuration offers a significant opportunity to reduce the cost of solar power.

Table 3 ISCCS Cost Reduction Potential

\begin{tabular}{lcc}
\hline Site: Kramer Junction & $\begin{array}{c}\text { Solar } \\
\text { Rankine }\end{array}$ & $\begin{array}{c}\text { ISCCS } \\
\text { Solar } \\
\text { Increment }\end{array}$ \\
\hline Plant size, net electric $(\mathrm{MWe})$ & 50 & $40^{2}$ \\
Collector aperture area $\left(\mathrm{km}^{2}\right)$ & 0.312 & 0.222 \\
Thermal storage (hours) & 0 & 0 \\
Solar-to-electric efficiency $(\%)$ & $13.9 \%$ & $15.7 \%$ \\
Plant capacity factor $(\%)$ & $29.2 \%$ & $29.2 \%$ \\
Capital cost $(\$ / \mathrm{kWe})$ & 2,745 & 1,988 \\
O\&M cost $(\$ / \mathrm{kWh})$ & 0.024 & 0.008 \\
Fuel cost $(\$ / \mathrm{kWh})$ & 0.000 & $0.003^{3}$ \\
LCOE $[(\$ \mathrm{kWh})$ & 0.110 & 0.073 \\
\hline
\end{tabular}

\section{Receiver Technology Development}

The Solel UVAC receiver tube is a significant advance over the previous Luz cermet receiver design [10].

Table 4 shows the key thermal and optical properties of both receivers. In addition, improving reliability of the receiver has a significant impact on the cost of energy. New O\&M procedures and are expected to improve receiver reliability at future plants. The new UVAC receiver should reduce the cost of electricity by about $17 \%$. Of this, approximately $7 \%$ is due to the improved solar transmittance of the glass envelope, $2 \%$ is due to improved solar absorptance of the black absorber, $5 \%$ is due to reduced thermal emittance of the absorber, and $3 \%$ is due to improved receiver reliability. With continued development of receiver design and selective coatings, further improvements in receiver tube properties and reliability are believed to be possible. Targets of $96 \%$ absorptance and a $7 \%$ thermal emittance at $400^{\circ} \mathrm{C}$ appear to be feasible. Reducing receiver failures to $0.5 \%$ per year and improving properties can reduce the cost of energy by an additional $5 \%$. Of this, approximately $2 \%$ is from the improved solar absorptance, $2 \%$ from the improved thermal emittance, and $1 \%$ from the improved receiver reliability.

\footnotetext{
${ }^{2}$ The full ISCCS capacity would be much larger (e.g., on the order of 310 MWe).

${ }_{3}^{3}$ Due to lower Rankine cycle efficiency when solar is not available, additional natural gas must be burned to achieve the same electric output as the reference combined cycle plant.
}

Table 4 Trough Receiver Thermal/Optic Properties

\begin{tabular}{lccc}
\hline Site: Kramer Junction & $\begin{array}{c}\text { Luz } \\
\text { Cermet }\end{array}$ & $\begin{array}{c}\text { Solel } \\
\text { UVAC }\end{array}$ & $\begin{array}{c}\text { Future } \\
\text { Goal }\end{array}$ \\
\hline Data source & {$[11]$} & {$[12]$} & \\
Envelope solar transmittance & 0.915 & 0.96 & 0.96 \\
Coating solar absorptance & 0.915 & 0.941 & 0.96 \\
Coating thermal emittance & 0.14 & 0.091 & 0.07 \\
@ temperature $\left({ }^{\circ} \mathrm{C}\right)$ & 350 & 400 & 400 \\
Assumed annual failure rate & $5 \%$ & $2 \%$ & $0.5 \%$ \\
of glass envelope & & & \\
LCOE 2002\$ $/ \mathrm{kWh}$ & 0.133 & 0.110 & 0.104 \\
\hline
\end{tabular}

\section{Concentrator Size}

The size of the collector can have a significant effect on the cost. Luz increased the length and aperture of the LS-3 collector significantly from the LS-2 size. The EuroTrough consortium is looking to further increase the length of the collector [13]. We compare the cost of collectors that are the size of the LS-2, the size of the LS-3, and a collector that is 1.5 times as long as the LS-3 - similar to the EuroTrough design. This analysis assumed that the cost of the structure and mirrors are constant on a per-square-meter basis for all three sizes. This is not completely correct because the cost of the structure will be slightly higher for the larger sizes assuming similar structural stiffness [14]. However, the reduction in cost because of fewer interconnections, drives, electronics and controls, and receivers is a much more significant impact. For example, because the LS-3 uses the same receiver as the LS-2, but has a larger aperture, an LS-2 field of the same size would require $15 \%$ more receivers. Although not accounted for in this analysis, mirror costs on a per-square-meter basis are also likely to be lower for the LS-3 size mirrors in comparison to the LS-2 size. Table 5 shows a comparison of cost of the three sizes of collectors. Collector costs for this analysis are based on cost data from Pilkington [4].

Table 5 Effect of Concentrator Size on Cost of Energy

\begin{tabular}{lccc}
\hline Site: Kramer Junction & $\begin{array}{c}\text { LS-2 } \\
\mathbf{5 0}\end{array}$ & $\begin{array}{c}\text { LS-3 } \\
\mathbf{1 0 0}\end{array}$ & $\begin{array}{c}\text { LS-3 } \\
\mathbf{1 5 0}\end{array}$ \\
\hline Aperture $(\mathrm{m})$ & 5 & 5.75 & 5.75 \\
Length $(\mathrm{m})$ & 50 & 100 & 150 \\
Aperture area $\left(\mathrm{m}^{2}\right)$ & 235 & 545 & 818 \\
$\begin{array}{l}\text { Number of collectors } \\
\text { relative to LS-2 collector }\end{array}$ & $100 \%$ & $43 \%$ & $29 \%$ \\
$\begin{array}{l}\text { Number of receivers } \\
\text { relative to LS-2 collector }\end{array}$ & $100 \%$ & $87 \%$ & $87 \%$ \\
Estimated cost $\left(\$ / \mathrm{m}^{2}\right)$ & 233 & 208 & 202 \\
LCOE 2002 $\$ \mathrm{kWh}$ & 0.110 & 0.103 & 0.102 \\
\hline
\end{tabular}




\section{Thermal Energy Storage}

Some of the most significant advances in parabolic trough technology is the development of a thermal energy storage (TES) technologies that will work with the higher solar field operating temperatures required for the later more efficient SEGS plants.

A near-term TES option is a two-tank system that uses molten nitrate salt as the storage medium and has an oil-to-salt heat exchanger to transfer thermal energy from the solar field to the storage system [15]. When the storage system is discharged, the molten salt is circulated back through the heat exchanger to reheat the solar field heat-transfer fluid, which is then sent to the solar steam generator to make steam to operate the power plant. The thermal energy storage system described here is relatively expensive due to the need for a large oil-to-salt heat exchanger and the relatively small temperature difference between hot and cold storage tanks $\left(80-90^{\circ} \mathrm{C}\right)$, which means a larger storage volume is required than if a larger temperature difference were possible. The temperature difference in the storage system is currently constrained by upper temperature limit of the heat-transfer fluid $\left(400^{\circ} \mathrm{C}\right)$ on the hot side and the steam power cycle on the cold end.

Figure 2 shows the cost of energy from the 50-MWe plant with difference amounts of thermal storage [16]. Small amounts of thermal storage, up to 6 hours of full power output, result in an increase in the cost of energy, while storage capacities between 6 and 16 hours lower the cost of energy. It should be noted that small capacities might still be warranted by virtue of revenue considerations because they would allow the plant to dispatch solar power during the time of day with the highest electricity rates. Note that the lowest cost of energy occurs with approximately 12 hours of TES. Increasing TES beyond 12 hours results in increased dumping of energy during the summer when the plant would already be operating 24 hours a day.

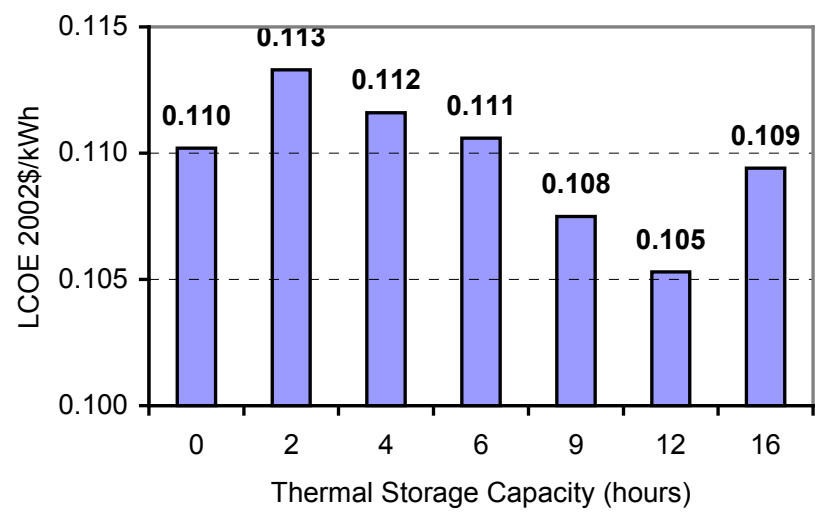

\section{Figure 2 Effect of Thermal Storage on Cost of Energy}

A number of advanced storage concepts have been identified that have the potential to significantly reduce the cost of thermal energy storage for parabolic trough plants. The current near-term TES option has a unit cost of $\$ 30$ to $40 / \mathrm{kWh}_{\mathrm{t}}$ depending on storage capacity. For comparison, the cost of storage for large molten-salt power towers, with a larger operating temperature difference, is expected to be less than $\$ 10 / \mathrm{MWh}_{\mathrm{t}}$ [5]. Three approaches are considered for reducing TES costs for troughs. The first is to move from a two-tank system to a single tank thermocline storage system. The second is to go from an indirect system that requires a heat exchanger to one that uses the same fluid in the solar field and storage system (similar to SEGS I or the Solar Two power tower). The third approach is to find a way to increase the hot and cold temperature differential in the storage system, thereby shrinking the storage volume required.

Pacheco [17] evaluated the thermocline TES system concept. This approach eliminates one of the storage tanks and allows most of the liquid stored in the tank to be replaced with a lower cost filler material, in this case quartzite rock and sand. The disadvantage of the thermocline is that there is a thermocline zone that occupies part of the tank, which reduces the useful capacity of the tank and also causes an increase in solar field supply temperature at end of the charge cycle as well as a decay in supply temperature to the power plant at the end of the storage discharge cycle. Appropriate design measures must be taken to maintain a tight thermocline zone in the storage system. The use of the thermocline can reduce the cost of storage by $30 \%$ to $50 \%$, depending on the relative cost of liquid to the low cost filler material.

In the two-tank TES configuration, the heat exchanger and related equipment add between 15 to $30 \%$ to the total system cost. In addition, the heat exchanger reduces the maximum temperature difference between the hot and cold fluids. Therefore, eliminating the need for a heat exchanger will reduce the TES cost. In a recent study $[18,19]$, the use of molten-salts directly in the solar field as the heat-transfer fluid and the storage medium has been proposed. This concept eliminates the need for a heat exchanger and allows the solar field operating temperature to be increased to $450^{\circ} \mathrm{C}$ or possibly higher. The major concern with molten-salts as a heat-transfer fluid in a trough plant is the high freeze point. A ternary nitrate salt mixture has been identified that has a freeze point of approximately $120^{\circ} \mathrm{C}$. This temperature appears to make the use of molten-nitrate salt a possibility, although other issues such as loop freeze recovery, maintenance practices and ball-joint seals in molten salt remain technical issues.

Figure 3 below shows the potential impact of advanced thermal energy storage technologies on the cost of energy for a 50-MWe SEGS plant with 12 hours of thermal storage. The chart shows the cost of energy for a plant without thermal storage, a plant with the near-term storage options (a two-tank indirect system), an indirect thermocline system, a direct (molten salt) two-tank system operating at $450^{\circ} \mathrm{C}$, and direct thermocline molten-salt system operating at $450^{\circ} \mathrm{C}$ and $500^{\circ} \mathrm{C}$. The advanced thermal storage systems offer a $14 \%$ reduction in the cost of energy over the near-term thermal storage option. 


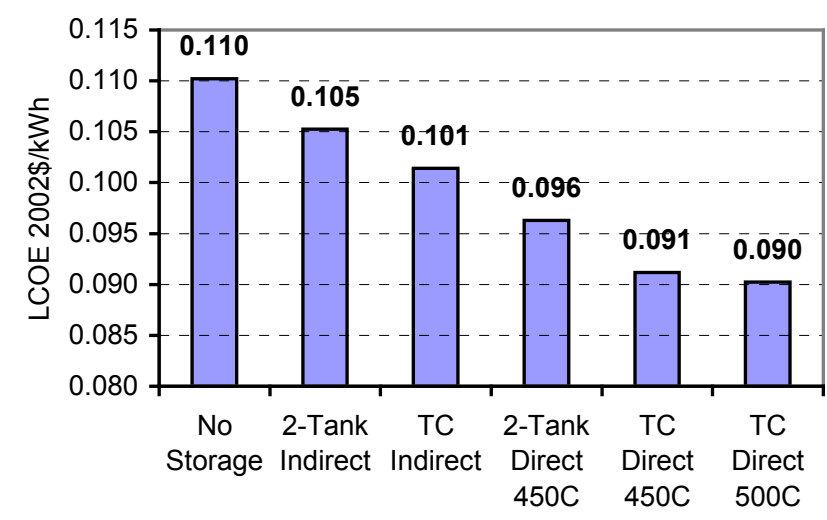

Figure 3 Impact of Advanced Storage Technologies on the Cost of Energy

The advanced TES cases shown in Figure 3 assume that inorganic molten salts are used as the heat-transfer fluid in the solar field. It should be noted that a number of alternative advanced TES concepts are being developed in parallel that may be used for these future higher temperature cases. NREL is currently working to develop organic salt heat-transfer fluids that remain liquid at ambient temperatures [20]. These fluids, if they can be developed to be stable at high temperatures and at a reasonable cost, could substantially reduce the technical risk of moving to a direct TES and a higher operating temperature in parabolic trough plants.

\section{Operation and Maintenance}

The KJCOC O\&M study [1] has shown that significant reductions in O\&M cost have been possible at the existing SEGS plants through improved equipment and methods. It is likely that not all of the O\&M cost reduction potential has been realized at the existing plants. Future plants will likely benefit from further improvements in O\&M equipment and methods, reductions in solar field spare part costs due to improved technology, increases in capacity factors through implementation of thermal energy storage, and economies of scale with scale-up in plant size and power park developments. All of these cost reductions were not explicitly illustrated above, but are implicitly included in the cost of energy.

\section{Financial Incentives}

Capital is the money invested to build a project. This is the complete cost including equipment, construction, and project development. There are two major types of capital investments in a project: equity and debt. The equity investment is made by the parties that will own the plant. Equity investments in typical independent power producer (IPP) projects require a 12 to $18 \%$ internal rate of return (IRR) after taxes. The debt investment is similar to a mortgage on a house. IPP projects typically use non-recourse debt, which simply means that the loan is secured by the cash flow of energy sales from the project and the debt investors cannot go after the owners if the project cannot make the loan payments.

A primary difference between solar and fossil plants is that the solar plant has a large solar field that is equivalent to a 30year fuel supply at the fossil plant and that incurs a high frontend capital investment. Even if the capital cost of the solar field is the same as the fuel cost at the fossil plant, the cost of power from the solar plant will end up being more expensive primarily because of two factors. First any capital investment must be paid back to investors at a high rate of return. Second, tax policy typically treats capital investment less favorably than expense type investments such as fuel. Access to low-cost capital can significantly reduce the cost of solar power. Our baseline 50-MW trough plant assumes an IRR to equity of $14 \%$ and a debt interest rate of $8.5 \%$. Figure 4 shows the impact on the cost of energy from our baseline 50 MWe plant for different debt interest rates and equity IRRs when the other is held constant. The availability of low cost sources of debt and equity capital can significantly reduce the cost of energy from capitalintensive solar plants. A more detailed discussion of project finance for trough plants is presented by Kistner and Price [21].

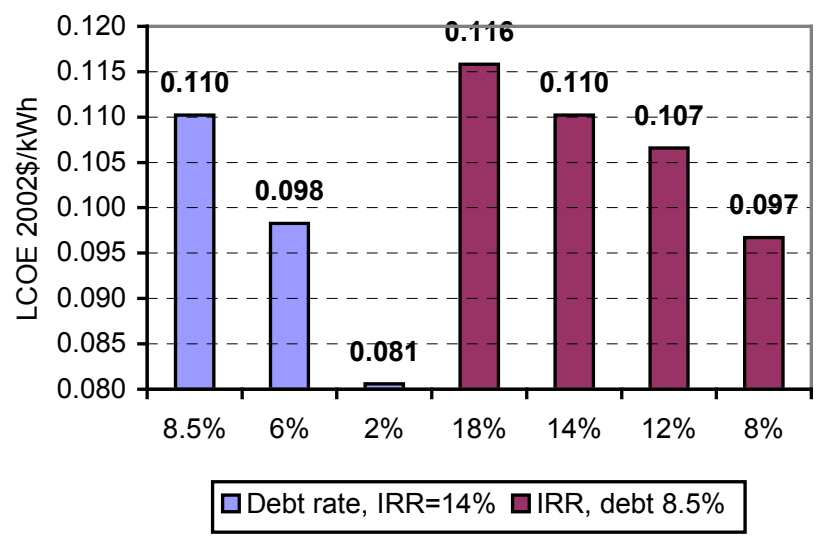

Figure 4 Effect of the Cost of Capital on the Cost of Energy

As previously mentioned, taxation policy tends to penalize capital-intensive solar projects. Without special property tax exemptions, a solar power plant would be forced to pay property tax on the solar field land and equipment. Because the solar field represents a major portion of the total capital cost of the plant, property tax on this equipment represents a significant cost penalty for solar technologies. Similarly, fossil plants also do not pay sales tax on their fuel. To help achieve tax neutrality with fossil technology, solar plants should be exempted from paying sales tax on solar equipment. In addition, because of the greater amount of capital investment for solar plants, the state and federal governments collect more taxes on the income received by debt and equity investors. Thus, the state and federal governments can offer special incentives to help encourage investment in capital-intensive renewable technologies and still remain whole through increased tax revenues. 
Historically, several types of incentives have been offered to renewable energy technologies. The SEGS plants benefited from federal and state investment tax credits (ITC) ranging from 10 to $50 \%{ }^{4}$ of the capital investment. A $10 \%$ federal ITC is currently still in place. The SEGS plants also benefited from a property tax exemption on all solar equipment, which is currently still in existence in California. The ITCs proved to be very successful for encouraging the development of the SEGS plants. Currently production-based incentives are the preferred approach for encouraging the development of a healthy renewables industry. A $1.8 \notin / \mathrm{kWh}$ production tax credit (PTC) is currently available to wind and biomass technologies and is largely responsible for the rapid growth in wind capacity in the United States. The $1.8 \mathrm{k} / \mathrm{kWh}$ PTC is also being considered for large-scale solar technologies, but is currently not sufficient to encourage near-term projects. In the recent DOE 1000-MWe CSP Report [22], tax incentives including a $1.8 \notin / \mathrm{kWh}$ PTC and a 30\% ITC were considered necessary in the short term to help CSP technologies be competitive.

Figure 5 shows the impact on the cost of power with different tax incentives. Note that the current $10 \%$ ITC already reduces the cost of power by almost $1 \notin / \mathrm{kWh}$ from the case with no ITC. The $1.8 \notin / \mathrm{kWh}$ PTC is only marginally better than the current $10 \%$ PTC. The last bar shows the impact of the $30 \%$ ITC, the $1.8 \notin / \mathrm{kWh}$ PTC, and property tax exemption. These incentives reduce the cost of power to under $8 \phi / \mathrm{kWh}$ for the near-term solar-only 50-MWe trough plant.

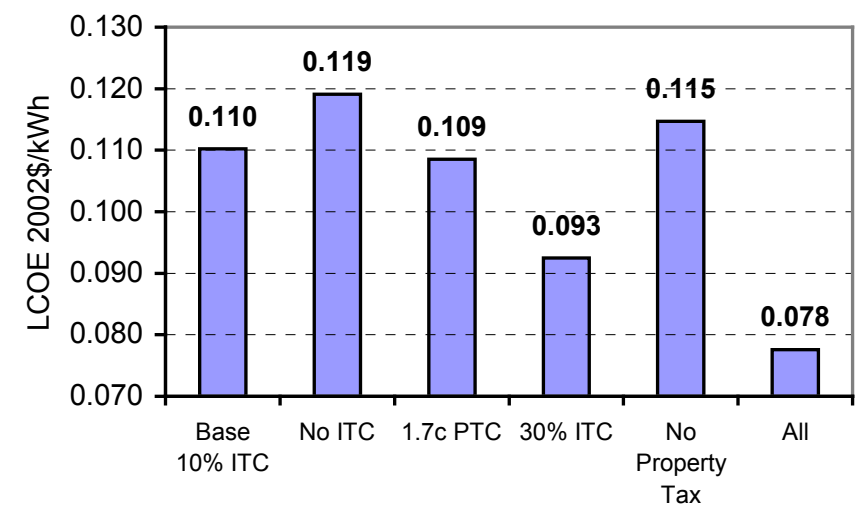

Figure 5 Effect of Tax Incentives on the Cost of Energy

\section{Site Solar Resource}

The direct normal solar resource has a significant impact on project economics. For the most part, the analysis presented in this paper uses the 1999 solar resource data from Kramer Junction, California. Table 6 shows the effect of site solar resource on the cost of energy for the baseline near-term trough plant for other locations. This highlights the need for finding

${ }^{4}$ During 1984-86 the SEGS projects benefited from a $10 \%$ Federal Investment Tax Credit, a 15\% Federal Energy Tax Credit, and a 25\% California Solar Energy Tax Credit [8].

sites with good solar resources. This also shows the importance of having good solar resource data for the specific plant site.

Table 6 Effect of Solar Resource on the Cost of Energy

\begin{tabular}{lccc}
\hline Site & $\begin{array}{c}\text { DNI } \\
\text { Resource } \\
\mathbf{k W h} / \mathbf{m}^{\mathbf{2}} \mathbf{y r}\end{array}$ & $\mathbf{\text { LCOE }}$ & Source \\
& 2,940 & 0.110 & $\mathrm{a}$ \\
\hline Kramer Junction, Calif. & 2,792 & 0.115 & $\mathrm{~b}$ \\
Daggett, Calif. & 2,606 & 0.125 & $\mathrm{~b}$ \\
Las Vegas, Nevada & 2,519 & 0.124 & $\mathrm{~b}$ \\
Phoenix, Ariz. & 2,488 & 0.127 & $\mathrm{~b}$ \\
El Paso, Texas & 2,340 & 0.147 & $\mathrm{~b}$ \\
Cedar City, Utah & 2,333 & 0.147 & $\mathrm{~b}$ \\
Reno, Nevada &
\end{tabular}

Source: a - KJC Operating Company, 1999 DNI data b - NREL TMY 2 Data, http://rredc.nrel.gov/

\section{FUTURE COST POTENTIAL}

In looking at the potential future cost of parabolic trough technology, two advanced technology scenarios are considered.

Mid-term scenario:

- 100-MWe Plant

- molten-salt HTF operating at $450^{\circ} \mathrm{C}$.

- thermocline TES with 12 hours of storage

- larger LS-3 collector aperture and $150 \mathrm{~m}$ length

- Improved receiver with $96 \%$ absorptance and $7 \%$ emittance at $400^{\circ} \mathrm{C}$

- $5 \%$ cost reduction from current due to production volume

Long-term scenario:

- 400-MWe Plant

- Molten-salt HTF operating at $500^{\circ} \mathrm{C}$.

- Thermocline TES with 12 hours of storage

- Same collector and receiver assumptions

- $20 \%$ cost reduction from current due to production volume.

Table 7 shows the key cost and performance parameters of the current, near-term, and future parabolic trough plants.

Table 7 Technology Characteristics and Cost

\begin{tabular}{lcccc}
\hline Case & $\begin{array}{c}\text { SEGS } \\
\text { VI }\end{array}$ & $\begin{array}{c}\text { Near- } \\
\text { Term }\end{array}$ & $\begin{array}{c}\text { Mid- } \\
\text { Term }\end{array}$ & $\begin{array}{c}\text { Long- } \\
\text { Term }\end{array}$ \\
\hline Size, MWe & 30 & 50 & 100 & 400 \\
Solar field size, $\mathrm{km}^{2}$ & 0.19 & 0.31 & 1.03 & 3.91 \\
Solar field cost, $\$ \mathrm{~m}^{2}$ & 234 & 245 & 184 & 122 \\
TES size, hours & 0 & 0 & 12 & 12 \\
TES cost, $\$ \mathrm{kWh}$ & $\mathrm{na}$ & $\mathrm{na}$ & 14 & 13 \\
Power block, $\$ / \mathrm{kWe}$ & 1022 & 854 & 657 & 363 \\
Annual capacity factor & $22 \%$ & $29 \%$ & $56 \%$ & $56 \%$ \\
Solar-to-electric & $10.6 \%$ & $13.9 \%$ & $16.2 \%$ & $17.2 \%$ \\
efficiency & & & & \\
Total capital cost, $\$ / \mathrm{kWe}$ & 3,008 & 2,745 & 3,416 & 2,225 \\
O\&M cost, $\$ \mathrm{kWh}$ & 0.046 & 0.024 & 0.010 & 0.006 \\
\hline & & & &
\end{tabular}


For this analysis, we consider four different financing scenarios. The first assumes the current financial incentives for an IPP power project. The second assumes the $1.8 \mathrm{k} / \mathrm{kWh}$ PTC in place of the $10 \%$ ITC. The third assumes the $30 \%$ ITC, the $1.8 \notin / \mathrm{kWh}$ PTC, and a property tax exemption. The final case is similar to the low-cost capital assumption, which assumes that the project is purchased by a municipal utility. Municipal utilities have access to low cost financing with interest rates as low as $6 \%$.

Figure 6 shows the results of the analysis for the current and future plants for each of the financing scenarios. The analysis shows that parabolic trough technology has significant potential for reducing the future cost of energy. The cost of energy forecast for future parabolic trough technologies can be very competitive with fossil power if $5 \notin / \mathrm{kWh}$ is the target. Financial incentives can be used to help make near-term projects more competitive. The $1.8 \notin / \mathrm{kWh}$ PTC is slightly more attractive than the current $10 \%$ ITC for the baseline parabolic trough plant; however, the PTC becomes much more attractive in the future when the capital cost and thus the value from the ITC is reduced. However, increased incentives, municipal financing, or special above market prices are likely to be necessary in the short-term.

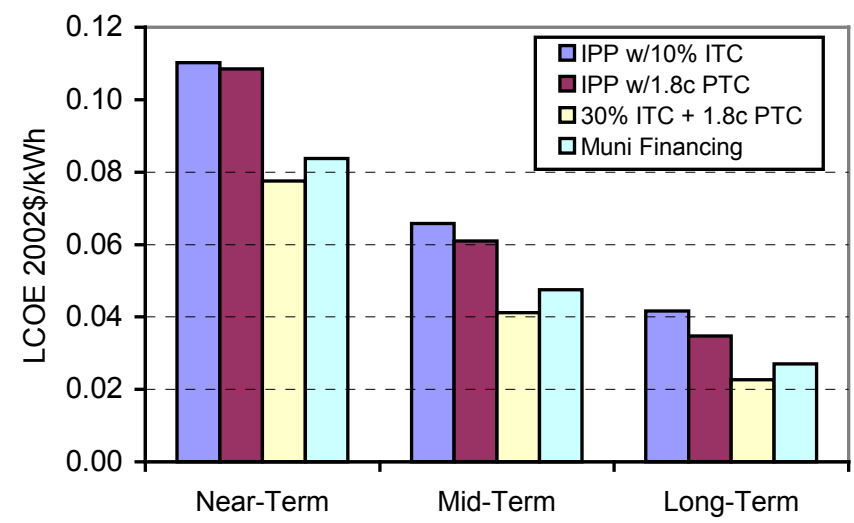

Figure 6 The Cost of Energy for Near-Term and Future Parabolic Trough Power Plants with different Financing Assumptions

\section{CONCLUSIONS}

Many factors have an effect on the cost of power: plant configuration, size, financing structure, and tax incentives. Even for current technology there is a wide range in costs for potential near-term plants. The costs presented here are for plants located in the Mojave Desert. The cost of power would be higher for locations with a lower solar resource.

There is significant opportunity for reducing the cost of power from parabolic trough power plants. Under various realistic scenarios, future plants appear to have the potential to directly compete with fossil power. While increasing plant size offers the easiest opportunity for reducing the cost of power, a number of technology advances have been identified that can also significantly reduce costs. These include increasing the collector size, improvements in receiver selective coatings, and development of advanced thermal storage technologies.

Financial incentives, market incentives such as renewable portfolio standards, and other approaches such as hybridization or integration into combined cycle power plants may be necessary to encourage near-term projects to be realized and set the stage for accelerated growth of this attractive large-scale solar technology.

\section{NOMENCLATURE}

CSP Concentrating Solar Power Program at DOE

DNI Direct Normal Insolation

DOE U.S. Department of Energy

FERC Federal Energy Regulatory Commission

GEF Global Environment Facility

HTF heat-transfer fluid

IPP independent power producer

IRR internal rate of return

ITC investment tax credit

ISCCS integrated solar combined cycle system, a trough solar plant integrated with a combined cycle power plant

KJCOC KJC Operating Company, operator of SEGS III-VII

LCOE Levelized cost of energy

LS-2 Luz second generation parabolic trough collector

LS-3 Luz third generation parabolic trough collector

MWe Mega-watt electric

O\&M operation and maintenance

NREL National Renewable Energy Laboratory

PTC production tax credit

R\&D Research and development

SEGS solar electric generating system

TES thermal energy storage

TMY typical meteorological year

UVAC Solel Universal Vacuum parabolic trough receiver

\section{ACKNOWLEDGMENTS}

The authors thank the parabolic trough industry in the United States., Europe, and Israel and KJC Operating Company for their contributions to this work. We also thank the U.S. DOE CSP program for their support of this effort.

\section{REFERENCES}

[1] Cohen, G., Kearney, D., and Kolb, G., 1999, "Final Report on the Operation and Maintenance Improvement Program for CSP Plants," Report No. SAND99-1290, Sandia National Laboratory: Albuquerque, NM.

[2] Price, H., and Kearney, D., 1999, "Parabolic-Trough Technology Roadmap: A Pathway for Sustained Commercial Development and Deployment of ParabolicTrough Technology," NREL/TP-550-24748, National Renewable Energy Laboratory: Golden, CO. 
[3] Price, H., 2003, "A Parabolic Trough Solar Power Plant Simulation Model," Proceedings of ISES 2003: International Solar Energy Conference, Hawaii, 16-18 March 2003.

[4] Pilkington Solar International GmbH, 1999, "Solar Steam System Investment Cost," Prepared for NREL by Pilkington, Köln, Germany.

[5] Sargent \& Lundy, 2002, "Assessment of Parabolic Trough and Power Tower Solar Technology Cost and Performance Forecasts," Prepared for U.S. Department of Energy and National Renewable Energy Laboratory: Chicago, IL, October 2002.

[6] Owens, B., 2002, "Economic Valuation of a Geothermal Production Tax Credit," NREL/TP-620-31969, National Renewable Energy Laboratory: Golden, CO.

[7] Leitner, A., 2002, "Fuel from the Sky: Solar Power's Potential for Western Energy Supply," RDI Consulting, NREL/SR-550-32160, July 2002.

[8] Lotker, M., 1989, "Solar Energy for Utility Peaking/Intermediate Load Duty: A Cost-Effective Option for the 1990s," Presented at the 1989 Electric Utility Business Environment Conference and Exhibition, Luz International Limited, Los Angeles, CA. March 29, 1989.

[9] Dersch, J., Geyer, M., Hermann, U., Jones, S., Kelly, B., Kistner, R., Ortmanns, W., Pitz-Paal, R., and Price, H., 2002, "Solar Trough Integration Into Combined Cycle Systems," Proceedings of the National Solar Energy Conference, Solar 2002, Reno/Sparks, Nevada, June 2002.

[10] Price, H., Lüpfert, E., Kearney, D., Zarza, E., Cohen, G., Gee, R., and Mahoney, R., 2002, "Advances in Parabolic Trough Solar Power Technology," Journal of Solar Energy Engineering, Volume 124, Number 2, May 2002.

[11] Dudley, V. E., Kolb, G. J., Mahoney, A. R., 1994, “Test Results: SEGS LS-2 Solar Collector," Report No. SAND94-1884, Sandia National Laboratory, Albuquerque, NM.

[12] Solel Solar Systems, 2001, Solartechnik Prufung Forschung: October 29, 2001-Solel Absorber Sample (SOL10111000Z), Beit Shemesh, Israel.

[13] Geyer, M., Lüpfert, E., Osuna, R., Esteban, A., Schiel, W., Schweitzer, A., Zarza, E., Nava, P., Langenkamp, J., Mandelberg, E., 2002, "EuroTrough - Parabolic Trough Collector Developed for Cost Efficient Solar Power Generation," Proceedings of the $11^{\text {th }}$ SolarPACES International Symposium on Concentrated Solar Power and Chemical Energy Technologies, September 4-6, 2002, Zurich, Switzerland.

[14] Gee, R., 2002, "Parabolic Trough Space Frame Structural Analysis," USA-Trough Initiative: Advanced Parabolic Trough System Design - Subtask 1.1 Final Report NREL Subcontract No. NAA-1-30441-06, Duke Solar Energy, Arvada, Colorado, May 7, 2002.
[15] Herrmann, U., Kelly, B., and Price, H., 2002, “Two-Tank Molten Salt Storage for Parabolic Trough Solar Power Plants," Proceedings of the $11^{\text {th }}$ SolarPACES International Symposium on Concentrated Solar Power and Chemical Energy Technologies, September 4-6, 2002, Zurich, Switzerland.

[16] Kearney, D, Kelly, B., Herrmann, U., Cable, R., Pacheco, J., Mahoney, R., Price, H., Blake, D., Nava, P., and Potrovitza, N., 2002, "Evaluation of a Molten Salt Heat Transfer Fluid in a Parabolic Trough Solar Field," Proceedings of the National Solar Energy Conference, Solar 2002, Reno/Sparks, Nevada, June 2002.

[17] Pacheco, J., Showalter, S., and Kolb, W., 2002, "Development of a Molten-Salt Thermocline Thermal Storage System for Parabolic Trough Plants," Journal of Solar Energy Engineering, Volume 124, Number 2, May 2002.

[18] Kearney, D, Kelly, B., Herrmann, U., Cable, R., Pacheco, J., Mahoney, R., Price, H., Blake, D., Nava, P., and Potrovitza, N., 2002, "Evaluation of a Molten Salt Heat Transfer Fluid in a Parabolic Trough Solar Field", Proceedings of the National Solar Energy Conference, Solar 2002, Reno/Sparks, Nevada, June 2002

[19] Kearney, D, Kelly, B., Herrmann, U., Cable, R., Pacheco, J., Mahoney, R., Price, H., Blake, D., Nava, P., and Potrovitza, N., 2002, "Engineering Aspects of a Molten Salt Heat Transfer Fluid in a Trough Solar Field," Proceedings of the $11^{\text {th }}$ SolarPACES International Symposium on Concentrated Solar Power and Chemical Energy Technologies, September 4-6, 2002, Zurich, Switzerland.

[20] Moens L., Blake D. M., Rudnicki, D. L., Hale, M. J., 2002, "Advanced thermal storage fluids for solar parabolic trough systems," Proceedings of the National Solar Energy Conference, Solar 2002, Reno/Sparks, Nevada, June 2002.

[21] Kistner, R., and Price, H., 1999, "Financing Solar Thermal Power Plants Proceedings of the ASME Renewable and Advanced Energy Systems for the 21st Century Conference, April 11-14, 1999, Maui, Hawaii.

[22] U.S. Department of Energy, 2002, "Report to Congress on: Feasibility of 1,000 Megawatts of Solar Power in the Southwest by 2006," Dept EERE, Washington, D.C., August 2002. 
Public reporting burden for this collection of information is estimated to average 1 hour per response, including the time for reviewing instructions, searching existing data sources,

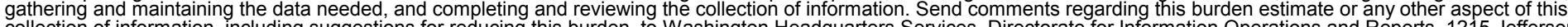
Davis Highway, Suite 1204, Arlington, VA 22202-4302, and to the Office of Management and Budget, Paperwork Reduction Project (0704-0188), Washington, DC 20503.
1. AGENCY USE ONLY (Leave blank)
2. REPORT DATE January 2003
3. REPORT TYPE AND DATES COVERED Conference Paper

4. TITLE AND SUBTITLE

Reducing the Cost of Energy from Parabolic Trough Solar Power Plants: Preprint
5. FUNDING NUMBERS

CP03.2000

6. $\mathrm{AUTHOR}(\mathrm{S})$

H. Price and D. Kearney

7. PERFORMING ORGANIZATION NAME(S) AND ADDRESS(ES)

National Renewable Energy Laboratory

1617 Cole Blvd.

Golden, CO 80401-3393

Kearney \& Associates, Vashon, WA

9. SPONSORING/MONITORING AGENCY NAME(S) AND ADDRESS(ES) AGENCY REPORT NUMBER

11. SUPPLEMENTARY NOTES

12a. DISTRIBUTION/AVAILABILITY STATEMENT

National Technical Information Service

U.S. Department of Commerce

5285 Port Royal Road

Springfield, VA 22161

13. ABSTRACT (Maximum 200 words) Parabolic trough solar technology is the most proven and lowest cost large-scale solar power technology available today, primarily because of the nine large commercial-scale solar power plants that are operating in the California Mojave Desert. However, no new plants have been built during the past ten years because the cost of power from these plants is more expensive than power from conventional fossil fuel power plants. This paper reviews the current cost of energy and the potential for reducing the cost of energy from parabolic trough solar power plant technology based on the latest technological advancements and projected improvements from industry and sponsored R\&D. The paper also looks at the impact of project financing and incentives on the cost of energy.

15. NUMBER OF PAGES

14. SUBJECT TERMS

parabolic trough; solar technology; SEGS; energy cost; thermal energy storage

17. SECURITY CLASSIFICATION OF REPORT Unclassified
18. SECURITY CLASSIFICATION OF THIS PAGE Unclassified
19. SECURITY CLASSIFICATION OF ABSTRACT Unclassified
16. PRICE CODE

20. LIMITATION OF ABSTRACT

UL

NSN 7540-01-280-5500

Standard Form 298 (Rev. 2-89) Prescribed by ANSI Std. Z39-18 